\title{
An empirical investigation on leanness of production planning
}

\author{
Jamshid Salehi Sadaghiani $^{\mathrm{a}}$, Hamed pourbakhsh ${ }^{\mathrm{b}}$, Hassan khodaei valehzaghard ${ }^{\mathrm{b}^{*}}$ and Pantea Salehi \\ Sadaghiani ${ }^{\mathrm{c}}$
}

${ }^{a}$ Department of Management and Accounting, Allameh Tabatabaee University, Tehran, Iran

${ }^{b}$ Ph.D, student of industrial management, Allameh Tabataba'i University, Tehran, Iran

${ }^{c}$ Department of Management, Islamic Azad University, UAE Branch, UAE

\begin{tabular}{|c|c|}
\hline C H R O N I C L E & A B S T R A C T \\
\hline $\begin{array}{l}\text { Article history: } \\
\text { Received October 28, } 2013 \\
\text { Received in revised format } \\
25 \text { November } 2013 \\
\text { Accepted } 26 \text { January } 2014 \\
\text { Available online } \\
\text { January } 282014 \\
\text { Keywords: } \\
\text { Lean production } \\
\text { Production planning } \\
\text { Total quality management }\end{array}$ & $\begin{array}{l}\text { One of the most important issues in production planning is to reduce waste materials as much } \\
\text { as possible. This helps reduce all necessary expenses and increase productivity and efficiency. } \\
\text { This paper presents an empirical investigation to find important factors for reaching lean } \\
\text { production planning. The proposed study determines nine different factors including } \\
\text { information technology, organization and leadership, human resources development, inventory } \\
\text { management, total quality management, process management, equipment management, } \\
\text { maintenance engineering. In order to find out the effects of these factors, the study designs a } \\
\text { questionnaire and distributes it among some managers in producer of radiator in Iran. Cronbach } \\
\text { alpha is equal to 0.86, which validates the questionnaire. Using some statistical observations, } \\
\text { the study has confirmed that all mentioned factors influences production planning, positively. }\end{array}$ \\
\hline
\end{tabular}

\section{Introduction}

For years, there were several studies on building a production firm with zero defect, no interruption in production line, reaching a desirable idea called lean production (LP) (Womack et al., 2007). Bonavia and Marin (2006), for instance, determined the degree of use of some of the most representative LP practices in the Spanish ceramic tile industry, their relationship with plant scale and their impact on the operational performance of the production firms in the sector. They presented data for reflecting on the application of various LP practices in isolation and on the impediments limiting the implementation of some of them in the sector. Soriano-Meier and Forrester (2002) presented a model for assessing the degree of leanness of manufacturing firms. They accomplished the survey among 30 companies in the UK ceramics tableware industry and represented a comprehensive overview of the state of play in that sector. There are different lean tools and models

*Corresponding author. Tel: +98-912-522223

E-mail addresses: Khodaei.God@gmail.com (H. Khodaei Valehzaghard) 
developed for process improvement and there are some discussions on a lean metrics to track the progress in production planning. Wan and Frank Chen (2008) proposed a unit-invariant leanness measure with a self-contained benchmark to measure the leanness level of manufacturing systems. Their proposed model is based on the idea of data envelopment analysis (DEA) and it extracts the leanness measure using some value-adding investments from a production process to determine the leanness frontier as a benchmark. They derived a linear program based on slacks-based measure to derive the leanness score, which indicated how lean the system was and how much waste existed. Using the score, they quantified the impacts of different lean initiatives as decision support information complementing the existing lean metrics. Bruun and Mefford (2004) explored the implications for lean production systems of the Internet and tried to determine whether the World Wide Web facilitate the implementation of Just-In-Time (JIT) production systems. The possible impacts on supply chains, production scheduling, inventory control, procurement, quality improvement, and the workforce were some of the issues discussed in this work. Karlsson and Åhlström (1996) developed a model, which operationalized various characteristics in lean production, with a concentration on those that concern the work organization in the manufacturing part of a company.

There are also several studies for detecting optimum strategies to reach lean production. Sánchez and Pérez (2001), for instance, performed an empirical investigation to determine lean indicators and manufacturing strategies.

\section{The proposed study}

This paper presents an empirical investigation to find important factors to reach lean production planning. The proposed study determines nine different factors including information technology, organization and leadership, human resources development, inventory management, total quality management, process management, equipment management, maintenance engineering. In order to find out the effects of these factors, the study designs a questionnaire and distributes it among some managers in producer of radiator in Iran. Cronbach alpha is equal to 0.86, which validates the questionnaire. The proposed study has applied Kolmogorov-Smirnov in order to understand whether the data are normally distributed or not and the results have confirmed that all data were normally distributed. There are nine hypotheses associated with the proposed study of this paper as follows,

1. Having a good access to information technology influences positively on reaching lean production planning.

2. Planning a suitable organization and leadership influences positively on reaching learn production planning.

3. A good human resources development influences positively on reaching lean production planning.

4. A good inventory management influences positively on reaching lean production planning.

5. Total quality management influences positively on reaching lean production planning.

6. Having a good production process positively on reaching lean production planning.

7. Process management influences positively on reaching lean production planning.

8. Taking care of equipment influences positively on reaching lean production planning.

9. Good maintenance engineering influences positively on reaching lean production planning. 


\section{The results}

In this section, we present details of our findings on testing nine hypotheses of the survey.

\subsection{The effect of Information technology on lean production planning}

The first hypothesis of this survey is associated with the effect of information technology on reaching lean production planning. Table 1 presents the summary of some statistical observation on testing the first hypothesis of the survey.

Table 1

The results of testing the relationship between information technology and lean production planning Mean-difference

\begin{tabular}{lcccccc}
\cline { 5 - 7 } Variable & Mean & Std. Dev. & t-student & Sig. & Min & Max \\
\hline Information technology & 5.93 & 1.054 & 14.27 & 0.000 & 5.22 & 6.47 \\
\hline
\end{tabular}

As we can observe from the results of Table 1, Information Technology is statistically meaningful when the level of significance is one percent. Therefore, we can conclude that information technology influences positively on reaching lean production planning.

\subsection{The effect of organization and leadership on lean production planning}

The second hypothesis of this survey is associated with the effect of organization and leadership on reaching lean production planning. Table 2 presents the summary of some statistical observation on testing the second hypothesis of the survey.

\section{Table 2}

The results of testing the relationship between organization \& leadership and lean production planning

\begin{tabular}{lcccccc}
\hline & & & & \multicolumn{2}{c}{ Mean-difference } \\
\cline { 5 - 7 } Variable & Mean & Std. Dev. & t-student & Sig. & Min & Max \\
\hline Organization and leadership & 4.05 & 1.035 & 11.17 & 0.014 & 3.57 & 4.56 \\
\hline
\end{tabular}

As we can observe from the results of Table 2, organization and leadership is statistically meaningful when the level of significance is one percent. Therefore, we can conclude that organization and leadership influences positively on reaching lean production planning.

\subsection{The effect of human resources development on lean production planning}

The third hypothesis of this survey is associated with the effect of human resources development on reaching lean production planning. Table 3 shows the summary of some statistical observation on testing the third hypothesis of the survey.

Table 3

The results of testing the relationship between human resources development and lean production planning

\begin{tabular}{lcccccc}
\hline & & & & & \multicolumn{2}{c}{ Mean-difference } \\
\cline { 5 - 7 } Variable & Mean & Std. Dev. & t-student & Sig. & Min & Max \\
\hline Human resources development & 4.89 & 1.132 & 13.86 & 0.000 & 4.11 & 5.48 \\
\hline
\end{tabular}

As we can observe from the results of Table 3, human resources development is statistically meaningful when the level of significance is one percent. Therefore, we can conclude that human resources development influences positively on reaching lean production planning. 


\subsection{The effect of inventory management on lean production planning}

The fourth hypothesis of this survey is associated with the effect of a good inventory management on reaching lean production planning. Table 4 presents the summary of some statistical observation on testing the fourth hypothesis of the survey.

Table 4

The results of testing the relationship between inventory management and lean production planning

\begin{tabular}{lcccccc}
\hline & & & & \multicolumn{2}{c}{ Mean-difference } \\
\cline { 5 - 7 } Variable & Mean & Std. Dev. & t-student & Sig. & Min & Max \\
\hline Inventory management & 5.49 & 1.724 & 12.94 & 0.000 & 4.14 & 6.35 \\
\hline
\end{tabular}

As we can observe from the results of Table 4, inventory management is statistically meaningful when the level of significance is one percent. Therefore, we can conclude that inventory management influences positively on reaching lean production planning.

\subsection{The effect of total quality management on lean production planning}

The fifth hypothesis of this survey is associated with the effect of a applying total quality management on reaching lean production planning. Table 5 presents the summary of some statistical observation on testing the fifth hypothesis of the survey.

\section{Table 5}

The results of testing the relationship between total quality management and lean production planning

\begin{tabular}{lcccccc}
\hline & & & & & \multicolumn{2}{c}{ Mean-difference } \\
\cline { 5 - 7 } Variable & Mean & Std. Dev. & t-student & Sig. & Min & Max \\
\hline Total quality management & 4.21 & 1.063 & 12.41 & 0.021 & 3.41 & 4.62 \\
\hline
\end{tabular}

As we can observe from the results of Table 5, total quality management is statistically meaningful when the level of significance is one percent. Therefore, we can conclude that total quality management influences positively on reaching lean production planning.

3.6. The effect of production process on lean production planning

The sixth hypothesis of this survey is associated with the effect of a applying production process on reaching lean production planning. Table 6 presents the summary of some statistical observation on testing the sixth hypothesis of the survey.

Table 6

The results of testing the relationship between production process and lean production planning

\begin{tabular}{lcccccc}
\hline & & & & & \multicolumn{2}{c}{ Mean-difference } \\
\cline { 5 - 7 } Variable & Mean & Std. Dev. & t-student & Sig. & Min & Max \\
\hline Production process & 5.12 & 1.19 & 15.76 & 0.000 & 4.42 & 5.98 \\
\hline
\end{tabular}

As we can observe from the results of Table 6, production process is statistically meaningful when the level of significance is one percent. Therefore, we can conclude that production process influences positively on reaching lean production planning.

\subsection{The effect of process management on lean production planning}

The seventh hypothesis of this survey is associated with the effect of having a good process management on reaching lean production planning. Table 7 presents the summary of some statistical observation on testing the seventh hypothesis of the survey. 
Table 7

The results of testing the relationship between process management and lean production planning

\begin{tabular}{lcccccc} 
& & & & & \multicolumn{2}{c}{ Mean-difference } \\
\cline { 6 - 8 } Variable & Mean & Std. Dev. & t-student & Sig. & Min & Max \\
\hline Process management & 4.93 & 1.643 & 14.35 & 0.01 & 4.68 & 5.17 \\
\hline
\end{tabular}

As we can observe from the results of Table 7, process management is statistically meaningful when the level of significance is one percent. Therefore, we can conclude that process management influences positively on reaching lean production planning.

\subsection{The effect of equipment management on lean production planning}

The eighth hypothesis of this survey is associated with the effect of having a good equipment management on reaching lean production planning. Table 8 presents the summary of some statistical observation on testing the eighth hypothesis of the survey.

\section{Table 8}

The results of testing the relationship between equipment management and lean production planning

\begin{tabular}{lcccccc} 
& & & & & \multicolumn{3}{c}{ Mean-difference } \\
\cline { 5 - 7 } Variable & Mean & Std. Dev. & t-student & Sig. & Min & Max \\
\hline Equipment management & 5.68 & 1.54 & 16.34 & 0.000 & 4.93 & 6.11 \\
\hline
\end{tabular}

As we can observe from the results of Table 8, equipment management is statistically meaningful when the level of significance is one percent. Therefore, we can conclude that equipment management influences positively on reaching lean production planning.

\subsection{The effect of equipment management on maintenance engineering}

The eighth hypothesis of this survey is associated with the effect of having a good engineering management on reaching lean production planning. Table 9 presents the summary of some statistical observation on testing the ninth hypothesis of the survey.

\section{Table 9}

The results of testing the relationship between engineering management and lean production planning

\begin{tabular}{lcccccc}
\hline & & & & \multicolumn{2}{c}{ Mean-difference } \\
\cline { 5 - 8 } Variable & Mean & Std. Dev. & t-student & Sig. & Min & Max \\
\hline Engineering management & 4.02 & 1.172 & 13.71 & 0.019 & 3.34 & 4.81 \\
\hline
\end{tabular}

As we can observe from the results of Table 9, engineering management is statistically meaningful when the level of significance is one percent. Therefore, we can conclude that engineering management influences positively on reaching lean production planning.

\section{Conclusion}

In this paper, we have presented an empirical investigation to detect important factors contributing on lean production planning. The proposed study determined nine various factors including information technology, organization and leadership, human resources development, inventory management, total quality management, process management, equipment management, maintenance engineering. Using some statistical observations, the study has confirmed that all mentioned factors influences production planning, positively. An in debt discussion with managers of this firms has disclosed that the proposed case study of this paper requires to improve their inventory systems and reduce the ordering expenses through choosing appropriate models. In addition, they need to improve their 
maintenance engineering systems to reduce production interruption as well as failures in their equipment. Finally, the system needs to improve their organizational structure by converting their chart into more horizontal form in order to improve communication between different parts of the system.

\section{Acknowledgement}

The authors would like to thank the anonymous referees for constructive comments received earlier.

\section{References}

Bonavia, T., \& Marin, J. A. (2006). An empirical study of lean production in the ceramic tile industry in Spain. International Journal of Operations \& Production Management, 26(5), 505-531.

Bruun, P., \& Mefford, R. N. (2004). Lean production and the Internet. International Journal of Production Economics, 89(3), 247-260.

Karlsson, C., \& Åhlström, P. (1996). Assessing changes towards lean production. International Journal of Operations \& Production Management,16(2), 24-41.

Sánchez, A. M., \& Pérez, M. P. (2001). Lean indicators and manufacturing strategies. International Journal of Operations \& Production Management,21(11), 1433-1452.

Soriano-Meier, H., \& Forrester, P. L. (2002). A model for evaluating the degree of leanness of manufacturing firms. Integrated Manufacturing Systems, 13(2), 104-109.

Wan, H. D., \& Frank Chen, F. (2008). A leanness measure of manufacturing systems for quantifying impacts of lean initiatives. International Journal of Production Research, 46(23), 6567-6584.

Womack, J. P., Jones, D. T., \& Roos, D. (2007). The machine that changed the world: The story of lean production--Toyota's secret weapon in the global car wars that is now revolutionizing world industry. SimonandSchuster. com. 